\title{
The Personality and Professional Practice Attitude of Civil Engineers in Construction Project in Thailand
}

\author{
Thawut Luangkaew \\ A Ph.D. student in Engineering Law and Inspection \\ Program, Faculty of Engineering, Ramkhamhaeng \\ University, Bangkok, Thailand \\ Waranon Kongsong \\ Assistant Professor, Department of Engineering Law and \\ Inspection, Faculty of Engineering, \\ Ramkhamhaeng University, Bangkok, Thailand. \\ ORCID: 0000-0003-2651-8476
}

\author{
Prachya Piyamanotham \\ Assistant Professor, Department of Psychology, \\ Faculty of Education, Ramkhamhaeng University, \\ Bangkok, Thailand. \\ Noppakorn Usahanunth \\ Lecturer, Faculty of Public Health, \\ Western University, Kanchanaburi, \\ Thailand.
}

\author{
Chaiwat Pooworakulchai \\ Lecturer, Department of Engineering Law and Inspection, \\ Faculty of Engineering, \\ Ramkhamhaeng University, Bangkok, Thailand.
}

\begin{abstract}
This research presents to study the personality and attitude in the professional practice of civil engineers who have been licensed from the Council of Engineers Thailand (COE Thailand) and work in construction projects by using the personality test and the developed attitude test with a sample of 307 people. The Results of the study found that personality type of civil engineers in the construction project is the most ESTJ personality (Extraversion, Sensing, Thinking, and Judgment) at $\mathbf{1 4 . 4 \%}$, discovered that Civil engineers in the construction project Thailand without the SP personality group. This reflects that the work of civil engineers in the construction project has characteristics that like to use too much work expertise, cutting various steps. The Pearson Correlation relationship between gender differences and personality types differ significantly with significance in personality, sensing, and Judgment which explains that different-sex of civil engineers in construction projects. There will be differences in the issues of skills, summary issues, and discretion. Including responsibility for duty. The different importance of attitudes in the engineering law profession and professional ethics, such as construction safety law and physical health.
\end{abstract} Test

Keywords-Personality Theory, Personality Test, Aptitude

\section{INTRODUCTION}

Civil engineer careers to be successful it must have the perseverance and love for the profession, which is particularly incumbent must have the skills, technical knowledge, ethics upheld. And must have interpersonal communication with individuals and other entities. The study of personality, professional engineers working in construction projects. Be aware of defects to bring improvement to develop into something even better in the future. The study can be adapted to the individual's right to comply with professional engineers who need to develop themselves. And keep up with changes in the current situation. [1], [2], [3], [4].

\section{THE OBJECTIVES AND THE INSTRUMENTS}

This research aims to study. The relationship between Personality type theories of personality Carl G Jung attitude in the practice of engineering in Civil Engineering. The civil engineer who has been licensed by the Council of Engineers Thailand (COE Thailand), control engineers and workers in the construction project. The instruments used in the study a personality test according to personality theories of Carl G. Jung developed a new condensed form (Short Version Survey) questionnaire of 32 questions and using multiple choice answers 5 Options and attitude in practice. Civil Engineering 4 in the questionnaire consists of 36 questions on attitudes engineering standards (ES) attitudes, legal, engineering, and other related laws (LAW) attitude, professional ethics (ETHIC) and attitude. The other side (OTHERS) [5], [6].

\section{PERSONALITY THEORIES}

Personality theories of Carl G. Jung classification (Type Theories) personality are 8: 1) a global dimension. With a focus on the world outside their own (Extraverts-E), 2) dimension of looking at the world with a focus on the inner self (Introverts-I), 3) dimensional perception. Directly from the senses (Sensing-S), 4) recognition that forecasts the future. Or from past experience (Intuition-N), 5) dimension of the decision. The main rationale (Thinking-T), 6) The decision by the feeling (Feeling-F), 7) dimension of life. A pattern rules (Judgment-J), and 8) lifestyle. Flexibly adapted to the situation. (Perception-P) would be a mix of personality in a different dimension to the personality 
types, 16 models (16 Types), which is the difference of the attitudes, perceptions, decisions, and way of life is ISTJ. / ISTP / ESTP / ESTJ / ISFJ / ISFP / ESFP / ESFJ / INFJ / INFP / ENFP / ENFJ / INTJ / INTP / ENTP / ENTJ. [7], [8], [9], [10], [11], [12].

\section{SAMPLING}

The samples are 380 engineers have engineer license from the Council of Engineers Thailand (COE Thailand) who working in construction project sites following the show in Table 1.

Table 1 Number of samples

\begin{tabular}{|c|c|c|c|}
\hline Field of Engineering & \multicolumn{3}{|c|}{ Sample } \\
\hline Civil Eng. & 305 & - & - \\
\hline Electrical Eng. & - & 33 & - \\
\hline Mechanical Eng. & - & 22 & - \\
\hline Environmental Eng. & - & 17 & - \\
\hline Industrial Eng. & - & 2 & - \\
\hline N/A & - & - & 1 \\
\hline \multirow{2}{*}{ Total } & 305 & 74 & 1 \\
\hline & \multicolumn{3}{|c|}{380} \\
\hline
\end{tabular}

Table 2 Field of civil engineering work in Professional Engineering and Controlled Professional Engineering B.E.2550 (2007)

\begin{tabular}{|c|c|c|c|}
\hline $\begin{array}{c}\text { A field in Professional Engineering } \\
\text { and Controlled Professional } \\
\text { Engineering B.E.2550 (2007) }\end{array}$ & $\mathbf{N}$ & $\%$ & $\begin{array}{c}\text { Personality } \\
\text { Types }\end{array}$ \\
\hline Design and Calculation & 147 & 38.7 & INFJ \\
\hline Construction Supervision & 100 & 26.3 & ESTJ \\
\hline Project Management & 58 & 15.3 & ESTJ \\
\hline
\end{tabular}

Table 3 Type of civil engineering work in Professional Engineering and Controlled Professional Engineering B.E.2550 (2007)

\begin{tabular}{|c|c|c|c|}
\hline $\begin{array}{c}\text { Type of Civil Engineering work in } \\
\text { Professional Engineering and } \\
\text { Controlled Professional Engineering } \\
\text { B.E.2550 (2007) }\end{array}$ & $\mathbf{N}$ & $\boldsymbol{\%}$ & $\begin{array}{c}\text { Personality } \\
\text { Types }\end{array}$ \\
\hline Buildings & 234 & 61.6 & ESTJ \\
\hline Highway and Railway & 33 & 8.7 & INTJ \\
\hline Water resource and Irrigation & 14 & 3.7 & ESTJ \\
\hline
\end{tabular}

Table 4 Business type in construction project

\begin{tabular}{|c|c|c|}
\hline Business type & N & $\%$ \\
\hline Contractor & 316 & 83 \\
\hline Consultants & 45 & 12 \\
\hline Government Agencies & 19 & 5 \\
\hline
\end{tabular}

\section{RESULTS}

1) Results showed that the sample of 380 engineers who work on construction project sites comprised 305 civil engineers, 33 electrical engineers, 17 environmental engineers. $78.2 \%$ of them were male and most of them aged $26-30$ years $(26.1 \%)$. They graduated with a bachelor's degree $(68.7 \%)$ and most likely possessed an active license for controlled professional engineering, the associate engineer level $(82.4 \%)$. They performed their tasks in accordance with Ministerial Regulation on a Determination of Field in Professional Engineering and Controlled Professional Engineering B.E.2550 (2007) on design and calculation (38.7\%), construction supervision or manufacturing $(26.3 \%)$, and project management $(15.3 \%)$.

2) The analysis of data Found that personality traits of the sample by professional engineering concluded that civil engineering, Electronic Engineering, Environmental Engineering Most of personality, personality and decision logic ( $\mathrm{T}$ : Thinking) were found to have an average rate of $81.5,71.67$ and 82.06 respectively, Mechanical engineering percent majority 95.68 personality types work using Plan (J: Judgment) The analysis of data Found that personality types of the civil and electrical engineers in construction projects that are most ESTJ $14.4 \%$ and $26.7 \%$ for mechanical engineers. The analysis of data Personality of Mechanical Engineering and environmental construction projects that are most ENFJ 40 and 50\%, respectively.

- Civil Eng. Electrical Eng. $\quad$ Mechanical Eng. Environmental Eng.

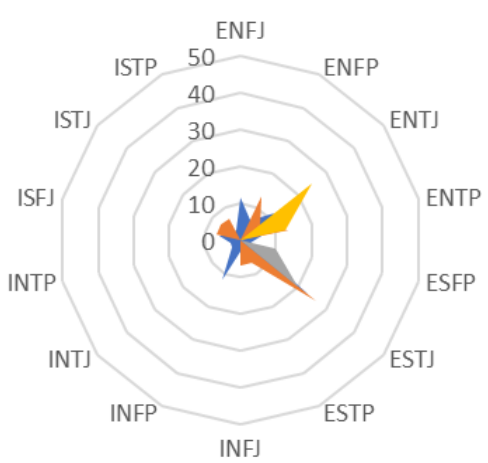

Fig. 1. Personality Types of Engineers in Construction Project

3) Data analysis results in types of personality types of civil engineers working on construction projects from the sample of 305 persons revealed that they most likely had an ESTJ personality (14.4\%), followed by INFJ and ISTJ personalities by $12.8 \%$ and $10.5 \%$.

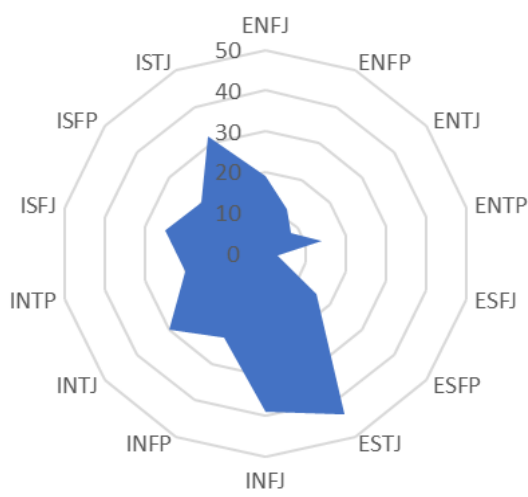

Fig. 2. Personality Types of Civil Engineers in Construction Project 
Table 5 Personality Types classify by Engineers License

\begin{tabular}{|c|c|}
\hline Engineers License from COE Thailand & $\begin{array}{c}\text { Personality } \\
\text { Types }\end{array}$ \\
\hline Associate Engineer & ESTJ \\
\hline Professional Engineer & ISFP \\
\hline Senior Professional Engineer & ESFP \\
\hline
\end{tabular}

4) Personality Type of civil engineer on construction projects that are ESTJ (Extraversion, Sensing, Thinking, and Judgment) looks like a reasonable man. Analytical decision to organize facts well. Planned actions as well as to advance an operating no personal relationships, too. When looking at the overall personality are 2 types that are not found in the personality of a civil engineer in construction projects is ISTP and ESTP, which belongs to the SP, which is typical behavior of a personality SP is a free spirit and action. Like dealing with the true flexibility so generous, so bargaining behavior that is missing from a civil engineer on the project construction is the lack of a decision. And cannot work in an environment with strict regulations as well. The less important disclosures to others excessive use of Savvy Make the cut at various stages of the decision should be guided and not be harsh to the feelings of others.

5) Materialism attaches to test the relationship between attitudes in the civil engineering professional branch engineer found that the trends in construction projects that cater to. Legal engineering will greatly tend to focus on the moral level, in contrast to.

6) Test the relationship between attitudes in the engineering profession Civil finds a trend those civil engineers in construction projects that cater to the standards. Engineering greatly usually people prefer more highbrow.

Table 6 Descriptive Statistics between Personality Types and Professional Practice Attitude of Civil Engineers

\begin{tabular}{|c|r|r|r|}
\hline & Mean & Std.Deviation & $\boldsymbol{N}$ \\
\hline ES & 3.5007 & .47765 & 255 \\
\hline LAW & 3.3917 & .60464 & 254 \\
\hline ETHIC & 3.6448 & .70021 & 252 \\
\hline OTHERS & 3.6472 & .61551 & 255 \\
\hline E & 3.6615 & .79132 & 305 \\
\hline I & 3.7680 & 1.25872 & 305 \\
\hline T & 3.9738 & .54309 & 305 \\
\hline F & 3.8180 & .98513 & 305 \\
\hline S & 3.9803 & .54375 & 305 \\
\hline $\mathbf{N}$ & 3.8025 & .61682 & 305 \\
\hline J & 4.0279 & .50941 & 305 \\
\hline P & 3.5713 & .49921 & 305 \\
\hline
\end{tabular}

7) Analyzes the relationship. The difference between sex with a personality (Traits) of Civil Engineers found that gender differences in civil construction projects. To pay attention to recognizing the uniqueness of each event. A summary of the procedure and the fact carefully studied. Including the responsibility to plan, including the organizing of things. The preparations live desk appliances.

Table 7 Group Statistics between sex and Professional Practice Attitude of Civil Engineers

\begin{tabular}{|c|c|r|r|r|r|}
\hline & \multicolumn{1}{|c|}{$\boldsymbol{S E X}$} & \multicolumn{1}{c|}{$\boldsymbol{N}$} & \multicolumn{1}{c|}{ Mean } & \multicolumn{1}{c|}{$\begin{array}{c}\text { Std. } \\
\text { Deviation }\end{array}$} & \multicolumn{1}{c|}{$\begin{array}{c}\text { Std. Error } \\
\text { Mean }\end{array}$} \\
\hline \multirow{2}{*}{ ES } & $\boldsymbol{M}$ & 206 & 3.5218 & .47848 & .03334 \\
\cline { 2 - 6 } & $\boldsymbol{W}$ & 40 & 3.3844 & .49710 & .07860 \\
\hline \multirow{2}{*}{ LAW } & $\boldsymbol{M}$ & 204 & 3.4603 & .49683 & .03479 \\
\cline { 2 - 6 } & $\boldsymbol{W}$ & 40 & 3.0000 & .91175 & .14416 \\
\hline \multirow{2}{*}{ ETHIC } & $\boldsymbol{M}$ & 202 & 3.7535 & .58803 & .04137 \\
\cline { 2 - 6 } & $\boldsymbol{W}$ & 40 & 3.0425 & .91003 & .14389 \\
\hline \multirow{2}{*}{ OTHERS } & $\boldsymbol{M}$ & 206 & 3.7015 & .54765 & .03816 \\
\cline { 2 - 6 } & $\boldsymbol{W}$ & 40 & 3.3062 & .85623 & .13538 \\
\hline
\end{tabular}

8) Analysis of different relationships. The difference between sexual attitudes of Civil Engineers. The engineer found a gender difference. The civil engineer on construction projects to care about Engineering law and other related laws such as Act, regulations requiring professional engineers, professional engineering, and control engineering. The regulations of the Council of Engineers for the ethics of professional engineering health safety in construction project and tolerance indifferent.

\section{REFERENCES}

[1] Waranon Kongsong and Seree Tuprakay (2008). Development of Integrated Engineering Curriculum. The Collection of Articles for the $6^{\text {th }}$ National Conference on Engineering Education, 14-16 May 2008.

[2] Thawut Luangkaew (2008). The Cause of Delay in Construction of Electric Train Connecting Suvarnabhumi Airport. Proceeding of the $13^{\text {th }}$ National Convention on Civil Engineering: "Civil Engineer Under the Sufficiency Economy Philosophy.", Jomtien Palm Beach Hotel and Resort, Pattaya.

[3] Thawut Luangkaew (2014). The guilty legislation of engineer and stakeholders case study: the collapse of a public building in Thailand. International Research Conference on Engineering Technology and Sciences - IRCETS 2014, Holiday Inn, Silom, Bangkok.

[4] Thawut Luangkaew (2014). The characteristics of professionals working in forensic engineering. International Research Conference on Engineering Technology and Sciences - IRCETS 2014, Holiday Inn, Silom, Bangkok.

[5] Thawut L, Kongsong W, Piyamanotham P, Usahanunth N, Development of Personality Test to Be Used With Engineers Working On Construction Project Sites in Thailand, International 
Journal of Engineering Research and Management (IJERM) Volume-06, Issue-05, May 2019, 16-18

[6] Luangkaew T, Kongsong W, Piyamanotham P, Usahanunth N, The Personality Type of Engineers in Construction Project in Thailand, International Journal of Engineering Research and Management (IJERM) Volume-06, Issue-05, May 2019, 27-30

[7] Myers, K. D., and Kirby, L. 1994. Introduction to type dynamics and development, exploring the next level of type, Consulting Psychologists Press, Inc., Mountain View, Calif.

[8] Myers, I. B., McCaulley, M. H., Quenk, N. L., and Hammer, A. L. 1998. MBTI Manual: A guide to the development and use of the Myers-Briggs Type Indicator, Consulting Psychologists Press, Inc., Mountain View, Calif.

[9] O'Brien, T.P., Bernold, L.E. and Akroyd, D. (1998) Myers Briggs Type Indicator and academic achievement in engineering education. International J. of Engineering Education, 14(5), 311-315.

[10] Brownsword, A. It Take All Type. New York: Consulting Psychologists Press, Inc., 1998.

[11] Kummerow, J. Talking in Type. New York: Center for Application of Psychological Type, 1985.

[12] M. H. McCaulley, E. S. Godleski, C. F. Yokomoto, L. Harrisberger, and E. D. Sloan, Applications of psychological type in engineering education, Engineering Education, 73, 5, (1983) pp. 394-400. 